ІСТОРИКО-ГЕНЕТИЧНИЙ АНАЛІЗ ВИТОКІВ ЕВРИСТИЧНИХ ОСВІТНІХ ІДЕЙ HISTORICAL-GENETIC ANALYSIS OF THE ORIGINS OF HEURISTIC EDUCATION IDEAS

УДК 37.015:575]:37.022(091)

DOI https://doi.org/10.32843/2663-

6085/2020/30-2.5

\section{Парфілова С.л.,}

канд. пед. наук,

доцент кафедри дошкільної

і початкової освіти

Сумського державного педагогічного

університету імені А.С. Макаренка

Пушкар л.В.,

канд. пед. наук,

доцент кафедри дошкільної

і початкової освіти

Сумського державного педагогічного

університету імені А.С. Макаренка
У статті розглянуто історичні аспекти сормування методів побудови умовиводів і розмірковувань евристичної педагогічної системи в епоху Античності та Середньовіччя. Здійснено огляд основних ідей сократівської діалогічної евристики і християнського світогляду. На основі проведеного порівняльного аналізу зазначених історичних періодів зроблено висновки, що мислителі Античності в ході діалогу фрормували поняття, тоді як учителі, які використовували методику катехізації, формували у свідомості учня образ на догоду сенсу поняття. Висвітлено характерні особливості педагогічної традиції Середньовіччя, здійснення освітнього процесу, який був пов'язаний зі структурно-функціональним устроєм суспільства, типом соціального наслідування суб'єктів освітнього процесу. З'ясовано, що саме «сократівська бесіда» стала одним із найбільш зорієнтованих на самостійність та активність самого учня методом безпосереднього спілкування 3 педагогом і навчання загалом, який одержав подальший розвиток на різних етапах становлення системи освіти. Розкрито функкиіонарну схему побудови сократівських діалогів, сутність якої зводиться до того, що необхідно спочатку зруйнувати систему помилкових уявлень і пов'язаних із нею суджень у свідомості учня, потім підвести його до підсумкового висновку й до того, що він нічого не знає з обговорюваного питання, а вже після цього на розчищеному підгрунті побудувати фрорму нових уявлень. Зроблено висновок, що Сократ став засновником першої в історії людства педагогічної системи, спрямованої на формування мислення через побудову понять. В основі чієї системи закладена єдність методологічного підходу (розумова діяльність учня) $і$ його методичної реалізації (підвідний діалог) у кожному конкретному випадку.

Практичне значення проведеного дослідження полягає в актуалізації конструктивного ретродосвіду. Подальших наукових розвідок потребує питання вивчення модифрікації вже відомих фоорм і методів шляхом евристичної транссрормації, наприклад, евристичний урок і його дидактичні можливості в освітньому прочесі сучасної початкової школи.

Ключові слова: евристика, евристичні діалоги, співрозмовник, свідомість учня, методика катехізації, самопізнання, побудова понять, придбання нових знань, фрормування мислення, педагогічна система.

The article considers historical aspects of forming the methods of constructing inferences and reasonings in heuristic pedagogical system in the epoch of Antiquity and the Middle Ages. The main ideas of Socratic dialogical heuristics and Christian worldview are reviewed. Based on the comparative analysis of these historical periods, it has been concluded that the thinkers of Antiquity formed a concept during the dialogue, while teachers who used the technique of catechesis, formed an image in the minds of students to please the meaning of the concept. The article reveals characteristic features of the pedagogical tradition of the Middle Ages, organization of the educational process, which was associated with the structural and functional order of society, the type of social imitation of the subjects of the educational process. It has been found that the "Socratic conversation" became one of the most focused on the independence and activity of the student methods through direct communication with the teacher and learning in general, which was further developed at different stages of the education system development. The functional scheme of constructing Socratic dialogues is revealed, the essence of which comes down to the fact that it is necessary to first destroy the system of misconceptions and related judgments in the mind of the student, then bring him to the final conclusion and to the fact that he knows nothing on the issue under discussion and only after that, to build the form of new ideas on the cleared ground. It is concluded that Socrates became the founder of the first in the history of mankind pedagogical system aimed at forming thinking through the construction of concepts. The basis of this system is the unity of the methodological approach (mental activity of the student) and its methodological implementation (input dialogue) in each case.

The practical significance of the study lies in updating of the constructive retro-experience. Further scientific research is needed to study the modification of already known forms and methods by heuristic transformation, for example, a heuristic lesson, and its didactic possibilities in the educational process of a modern primary school.

Key words: heuristics, heuristic dialogues, interlocutor, student's consciousness, catechesis technique, self-knowledge, construction of concepts, acquisition of new knowledge, formation of thinking, pedagogical system.
Постановка проблеми в загальному вигляді. У світлі завдань, поставлених перед національною освітою, та у зв'язку з реформою загальноосвітньої й профресійної школи, яка має на меті піднесення роботи вчителя на якісно новий рівень, що відповідає умовам і потребам сучасного суспільства, особливого значення набуває проблема формування евристичної діяльності учнів, спрямованої на конструювання власних знань і ство- рення освітніх продуктів, розвиток інтелектуальних і творчих задатків особистості.

Основою розвитку творчої особистості, фрормування стійкої пізнавальної мотивації до процесу навчання $€$ ситуації роздумів, активного пошуку нових знань, суперечливості суджень і здогадок. Такі ситуації створюються за допомогою методів колективного розв'язання проблем, які будуються як діалог учителя та учнів. Саме тому проблеми 
евристичної освіти, зокрема її найважливішого складника - евристичного діалогу як способу «відкриття» знань, способів комунікації та творчої навчальної діяльності, набувають сьогодні особливої актуальності.

Аналіз останніх досліджень і публікацій. Аналіз наукових джерел показав, що в педагогічній науці приділяється значна увага цій проблемі. Зокрема, роль евристики в науковому пізнанні розглядається в роботах В. Андрущенко, В. Бранського, А. Ракітова й інших. Цю проблему широко досліджували В. Соколов та А. Хуторський (дидактична евристика); В. Андрєєв, Ю. Кулюткін, Д. Пойя, Г. Саранцев, Л. Фрідман (евристика як методологія фрормування діяльності); О. Скафра (класифікація евристик).

Виділення не вирішених раніше частин загальної проблеми. Сьогодні існує низка концепцій, які свідчать про те, що евристика як самостійна наука ще не сорормувалася, а процес конструювання власних наукових знань відбувається хаотично. Тому постає завдання розглянути та критично оцінити історію зародження й розвитку педагогічної евристики.

Мета статті - здійснити аналіз зародження й подальшого становлення педагогічної системи евристичного навчання; визначити перспективні напрями подальших досліджень.

Виклад основного матеріалу. Історія питання про формування методів побудови умовиводів і розмірковувань сягає своїм корінням в епоху античності. Геніальне передбачення на інтуїтивному рівні шляхів вирішення цієї проблеми можна знайти в працях великих фрілософрів Стародавньої Греції - Сократа, Платона й Аристотеля.

Вивчаючи записи діалогів Сократа 3 його учнями, можна помітити чітку функціонарну схему побудови всіх діалогів. Сутність ії̈ зводиться до того, що необхідно передусім зруйнувати систему помилкових уявлень і пов'язаних із нею суджень у свідомості учня, а потім підвести його до підсумкового висновку й до того, що він нічого не знає з обговорюваного питання. Далі, зламавши так його упередженість, на розчищеному підґрунті побудувати форму нових уявлень, кожен етап розвитку якого виникав би у свідомості учня як щось об'єктивно неминуче, водночас як близьке, рідне, що зростає 3 власного «я». Сократ або обмежувався зіставленням довільно обраних одиничних випадків, або підводив учня до загальних фрормулювань визначення поняття, або, навпаки, знову-таки 3 довільного загального поняття прагнув з'ясувати, якою мірою ця спільність фрактично об'єднує зміст підпорядкованих понять. Так, наприклад, у діалозі Сократа й Евфідема $з$ питання про сенс поняття справедливості, наведеному в роботі Ксенофонта «Спогад про Сократа», Сократ не окреслює відразу коло цього поняття, але в ході діалогу тонко підво- дить свого співрозмовника до ухвалення кінцевого трактування свого визначення [2, с. 161-163].

Відзначаючи заслуги Сократа, Аристотель писав: «... по справедливості дві речі треба було б зарахувати на рахунок Сократа - індуктивні міркування й утворення загальних визначень: в обох цих випадках справа йде про початок знань» [1, с. 424].

Отже, можна зробити висновок, що Сократ став засновником першої в історії людства педагогічної системи, спрямованої на формування мислення через побудову понять. В основі системи Сократа закладена єдність методологічного підходу (розумова діяльність учня) і його методичної реалізації (підвідний діалог) у кожному конкретному випадку.

Педагогічна система Сократа не була виведена на рівень теоретичних узагальнень і технологій, а була радше інтуїцією, геніальною здогадкою. При цьому Сократ не турбувався про цілісність змісту, а використовував його лише як допоміжний матеріал, за допомогою якого він фрормував свідомість своїх учнів.

Учень Сократа, засновник першої Академії, Платон в основу своєї педагогічної системи поклав фрілософську теорію про устрій світу. Перебуваючи впевненим в існуванні світу ідей, світу вічних істин, Платон уважав, що будь-яке придбання нових знань $€$ лише процесом спогадів того, що людська душа знала в епоху свого доземного буття. Тому пізнання світу в поданні Платона нерозривно пов'язане із самопізнанням, метою якого $€$ свідомий розвиток у собі якостей, які наближують людину до світу ідей.

На відміну від свого учителя, Платон визначає мету навчання й виховання як формування в учня глибокого внутрішнього світу, який прагне до світу вічних ідей, а саме: 1) дослідження троїстих елементів душі; 2) установлення невідповідності внутрішнього світу зі світом ідей; 3) зміна внутрішнього світу згідно зі світом ідей. При цьому Платон уперше вибирає об'єктивний критерій досягнення цілей. Отже, у роботах Платона описана ідея рефлексії, яка застосовується до фрормування системи цінностей.

Аналіз робіт Платона показує, що він, як і Сократ, віртуозно володів мистецтвом побудови бесід з учнями. Однак, на відміну від системи Сократа, педагогічна система Платона мала фрілософсько-теоретичне обґрунтування.

Особливо відзначимо ту роль, яку відводив Платон учителю. Розглядаючи можливість кризових моментів між розумним і бунтівним початком душі, Платон вимагає від педагога профрілактичної роботи 3 метою фрормування у свідомості учня перешкод, здатних протистояти негативному впливу. Саме вчитель повинен насамперед дбати про постійне сходження свого учня з одного рівня наближення до світу ідей на інший, що і $є$ необхідною умовою кінцевого успіху. 
Установлення цієї послідовності передбачає й глибоке проникнення «ідеального керівника» в сукупність об'єктів вивчення, і всебічне знання ним особливостей свого учня. Платон став першим педагогом, що сорормулював вимогу доступності навчання. Корисним для учня, на думку Платона, може виявитися тільки той навчальний матеріал, який за ступенем складності і своїми властивостями відповідає його психологічним особливостям.

Апофеозом праць мислителів античності стали роботи геніального фрілософра того часу, учня Платона, Аристотеля. Він першим із мислителів обрав предметом своїх досліджень методи міркувань, якими користувалися його видатні попередники.

Дослідження методів у побудові умовиводів привело Аристотеля до висновку помилковості теорії Платона про існування світу ідей. Мислитель робить висновок про невід'ємність душі від тіла й відсутність індивідуального потойбічного життя, що докорінно змінює основи для побудови мети буття людини.

Від абстрактних прагнень людини до небесного щастя Аристотель доходить думки про необхідність гедоністичного існування людини на землі. Мету виховання він розуміє як триєдине завдання фрізичного, морального й розумового виховання: розвиток сильного та гарного тіла, розвиток активності й вольового початку, пізнання дійсності.

Аристотель зробив першу в історії педагогіки спробу дати фрілософрсько-психологічне обґрунтування своєї системи виховання й першу спробу вікової періодизації, керуючись головним чином біологічними міркуваннями. Слідом за Платоном він обґрунтує вимогу створення державних шкіл і надає опис їхньої діяльності, приділяючи велике значення дошкільному вихованню, особливо грі.

Перемога християнства в Європі призвела до зміни принципу побудови педагогічних систем. Якщо в період античної культури мета виховання фрормувалася на засадах фрілософських учень, висунутих мислителями, то 3 перемогою християнства світогляд повністю визначався церквою, «монополія на інтелектуальну освіту дісталася попам, і сама освіта прийняла тим самим переважно богословський характер» [3, с. 3]. Природно, що в цих умовах середньовічна культура концентрувалася навколо виховання релігійного ідеалу. Отже, у період середньовіччя відбувається перехід від різноманіття виховних ідеалів античності до єдиного християнського ідеалу.

В основу християнського ідеалу покладено звернення людини до свого внутрішнього світу, виховання моральності, пропаганда особистих чеснот - співчуття до знедолених, уваги до ближніх, милосердя. Завдання навчання й виховання відображали інтереси державної ідеології на шкоду особистісної значущості. Разом із тим звер- нення людини до свого внутрішнього світу фрормувало в ній такі найважливіші якості особистості, як самоаналіз і самодисципліна.

3'явилася необхідність у масовому навчанні, продумуванні механізмів передачі знань і контролю їх засвоєння. Уперше почав створюватися унітарний механізм діяльності - система навчання. Як наслідок, виникає єдність змісту, методів навчання й контролю, а також уніфрікована фрорма навчання - школа.

В історичній літературі метод навчання, що застосовувався в школах середньовіччя, прийнято називати катехізацією. Цей метод ссрормувався на основі діалогів, прийнятих при навчанні в античні часи. Однак у ранньохристиянських релігійних школах евристика античності змінилася вимогою запам'ятовування церковних догм.

Історія педагогіки дає змогу проаналізувати, як саме відбувався перехід від платонівських діалогів до катехізації. Як приклад розглянемо добре відомий випадок із записом уроку вчителя Алкуїна, який викладав у школі при дворі короля Карла Великого. У статті, присвяченій середньовічній педагогіці, профресор О.О. Фортунатов дає запис цього уроку, наведений самим Алкуїном у підручнику граматики:

«Були в школі вчителі Альбіна (Алкуїна) два хлопчики - один фрранк, інший сакс, які зовсім недавно вступили в лісову гущавину граматики. Тому їм захотілося отримати деякі правила словесної науки шляхом запитань і відповідей заради запам'ятовування. І ось перший із них - фрранк сказав Саксу: «Ну, сакс, відповідай на мої запитання, бо ти старший за віком. Мені 14, а тобі, я думаю, 15». На це сакс відповів: «Виконаю, але 3 тією умовою, що якщо питання торкнеться чого-небудь більш високого або фрілософрської дисципліни, то варто питати наставника». На це наставник сказав: «Подобається мені, діти, ваша пропозиція, і я охоче допоможу вашій допитливості. Але спочатку скажіть, з чого, вирушаючи, думаєте ви почати обговорення». Учень: «Від чого ж ще, пане наставнику, як не від букви». Учитель: «Добре надумали б ви, але якби раніше не згадали про фрілософію. Тому варто почати зі звуку людської мови, заради чого винайдені літери» [4, с. 76]. Тепер подивимося запис цього ж діалогу спостерігачами - представниками катехізаційного напряму: «Що є буква?» - «Страж історії».

Аналогічно в питально-відповідну форму переводилося вивчення інших понять, наприклад:

«Що таке слово?»- «Виразник душі». «Що народжує слово?» - «Мову». «Що $€$ мова?»«Батіг повітря». «Що таке повітря?» - «Охорона життя». «Що таке життя?» - «Радість блаженних, гордість нещасних, очікування смерті». «Що таке смерть?» - «Неминучий результат, мандрування в невідоме, сльози для живих, укладання 
заповіту, розбійник для людини». «Що таке людина?» - «Раб смерті, мандрівник, що йде, гість на місці» [4, с. 107].

Далі йдуть питання-відповіді анатомо-фрізіологічного характеру (що таке людина, її голова, тіло, борода, волосся, очі, ніс, лоб, серце, кров тощо), потім - питання космографрічного характеру (що таке небо, світло, день, сонце, місяць, земля, море) тощо. Питання й наступні відповіді мали відрізнятися якомога більшою визначеністю, щоб катехіни точно знали, як їм належить розуміти догми релігії або моральні положення: усвідомити для себе і твердо запам'ятати. Отже, така методика навчання призводила до відриву образу від змісту поняття й робила навчання позбавленим суті.

Висновки. Отже, на основі аналізу досягнень античних фрілософрів-педагогів у вирішенні проблеми евристичної освіти доходимо висновків, що зроблені спроби побудови системи освіти, причому під системою розуміли єдність мети, засобів і методів впливу на учня в процесі навчання; за допомогою уніфікації методу підвідного діалогу зроблені спроби реалізації єдиного методологічного підходу до навчання й на практиці окреслені шляхи її розв'язання.

Подальших наукових розвідок потребує питання вивчення модифікації вже відомих фрорм і методів шляхом евристичної трансформації, наприклад, евристичний урок і його дидактичні можливості в освітньому процесі сучасної початкової школи.

\section{БІБЛІОГРАФІЧНИЙ СПИСОК:}

1. Антологія світової фрілософії : у 4 т. / редкол. А.С. Левчун та ін. Харків : Основа, 2004. Т. 1. 580 с.

2. Жураковський Г.Є. Нариси 3 історії античної педагогіки. Київ : Либідь, 1976. 500 с.

3. Сунягин Г.Ф. Общая характеристика педагогики средневековья. Западноевропейская средневековая школа и педагогическая мысль. Москва : Просвещение, 2001. С. 3-12.

4. Фортунатов А.А. К вопросу о педагогической литературе раннего средневековья. Западноевропейская средневековая школа и педагогическая мысль. Москва : Просвещение, 1997. С. 75-124. 